\title{
The Medicinal Plants Used in Anjir Pulang Pisau, Central Kalimantan-Indonesia
}

\section{Susi Novaryatiin*, Indah Indah}

\section{Susi Novaryatiin*, Indah Indah}

Department of Pharmacy, Faculty of Health Science, Universitas Muhammadiyah Palangkaraya, Palangka Raya, Central Kalimantan, INDONESIA.

\section{Correspondence}

\section{Susi Novaryatiin}

Department of Pharmacy, Faculty of Health Science, Universitas Muhammadiyah Palangkaraya, Palangka Raya, Central Kalimantan, INDONESIA.

E-mail: susi_novaryatiin@yahoo.com History

- Submission Date: 19-08-2019;

- Review completed: 10-09-2019;

- Accepted Date: 10-09-2019.

\section{DOI : 10.5530/pj.2019.11.240}

Article Available online http://www.phcogj.com/v11/i6s

\section{Copyright}

(C) 2019 Phcogj.Com. This is an openaccess article distributed under the terms of the Creative Commons Attribution 4.0 International license.

\begin{abstract}
Background: The use of medicinal plants in Anjir Pulang Pisau Village has been carried out for a long time through knowledge that is passed down through generations to family members. But there is no documentation of local knowledge about medicinal plants. Objective: This study was aimed to investigate the use of medicinal plants in Anjir Pulang Pisau Village, Central Kalimantan-Indonesia. Methods: The data were collected through individual interviews using semi-structured interviews. Information regarding the local names of the plant, medicinal uses, parts used, methods of preparation, and administration route were documented. Results: A total of 28 medicinal plants were identified. The family Anacardiaceae, Lamicaeae, Poaceae, and Myrtaceae had the highest proportion of medicinal plants used ( $7 \%$ each). The most frequently utilized medicinal plant parts were roots $(47 \%)$. The plant species used to treat the high percentage of disease was Curcuma zedoaria (Christm.) Roscoe. (16\%). In terms of frequency of medicinal plant uses, the highest percentage of plant species $(21 \%)$ was used to treat wound. Majority of the plant remedies in this study were prepared by decoction $(40 \%)$, and most medicinal plant preparations were taken orally $(75 \%)$. Conclusion: Further research is needed to identify unidentified family and plant species. Pharmacognostical and pharmacological studies are also needed for the identification of chemical compounds and proving the efficacy of medicinal plants used by local people.
\end{abstract}

Key words: Ethnomedicine, Traditional Knowledge, Pulang Pisau, Kahayan Hilir, Curcuma zedoaria.

\section{INTRODUCTION}

Indonesia is a country with a mega biodiversity. Indonesia has 30,000 plant species, of which about 9,600 species are known to have medicinal properties and only 200 species have been utilized as raw materials in traditional medicine industries. This biodiversity richness needs to be explored, developed and utilized for the improvement of health and economic goals while maintaining its sustainability. ${ }^{1}$ Indonesia is not only rich in its biodiversity but it is also well known as a country with high diversity of ethnicities. Each ethnic group has extensive experienced in the utilization and conservation of biological and ecological diversity. This biocultural richness provided ethnobotanical researchers with endless research opportunities. ${ }^{2}$

Kalimantan is the largest island in Indonesia that is famous for its biodiversity. Beside that, there are knowledge of traditional medicine using plants that are passed on orally from generation to generation on indigenous ethnic in Kalimantan. These biodiversity are scattered all over Kalimantan island, one of which is in Central Kalimantan Province. Central Kalimantan with an area of $15,380,410$ hectares where about $70 \%$ is considered as forested area is the home of medicinal plant biodiversity. ${ }^{3,4}$

People in Anjir Pulang Pisau Village still use plants as a traditional medicine to cure diseases. Usefulness they know from the narrative of the parents, exchange ideas with other members of the community and the results of his own experience. This knowledge is hereditary delivered orally and generally passed down to family members. The advancement of science and technology was not able to simply eliminate the meaning of traditional medicine. Treatment in traditional ways is increasingly popular both domestically and abroad. The use of medicinal plants has traditionally been favored because it is believed to have no side effects as well as dangerous chemicals.

The growing development of natural-made medicinal products by pharmaceutical companies, causing research is being conducted in many countries with the aim of increasing the use of traditional medicine for the welfare of the human populations. ${ }^{5}$ There is no ethnomedicinal study in Anjir Pulang Pisau Village. Hence, the present study was initiated to investigate the medicinal plants usage in Anjir Pulang Pisau Village, Central Kalimantan-Indonesia.

\section{MATERIALS AND METHODS}

\section{Study area}

The study of an ethnomedicinal survey for medicinal plants was conducted in Anjir Pulang Pisau Village which located in Kahayan Hilir District of Pulang Pisau Regency, Central Kalimantan-Indonesia (Figure 1). Pulang Pisau Regency is part of Central Kalimantan Province, 

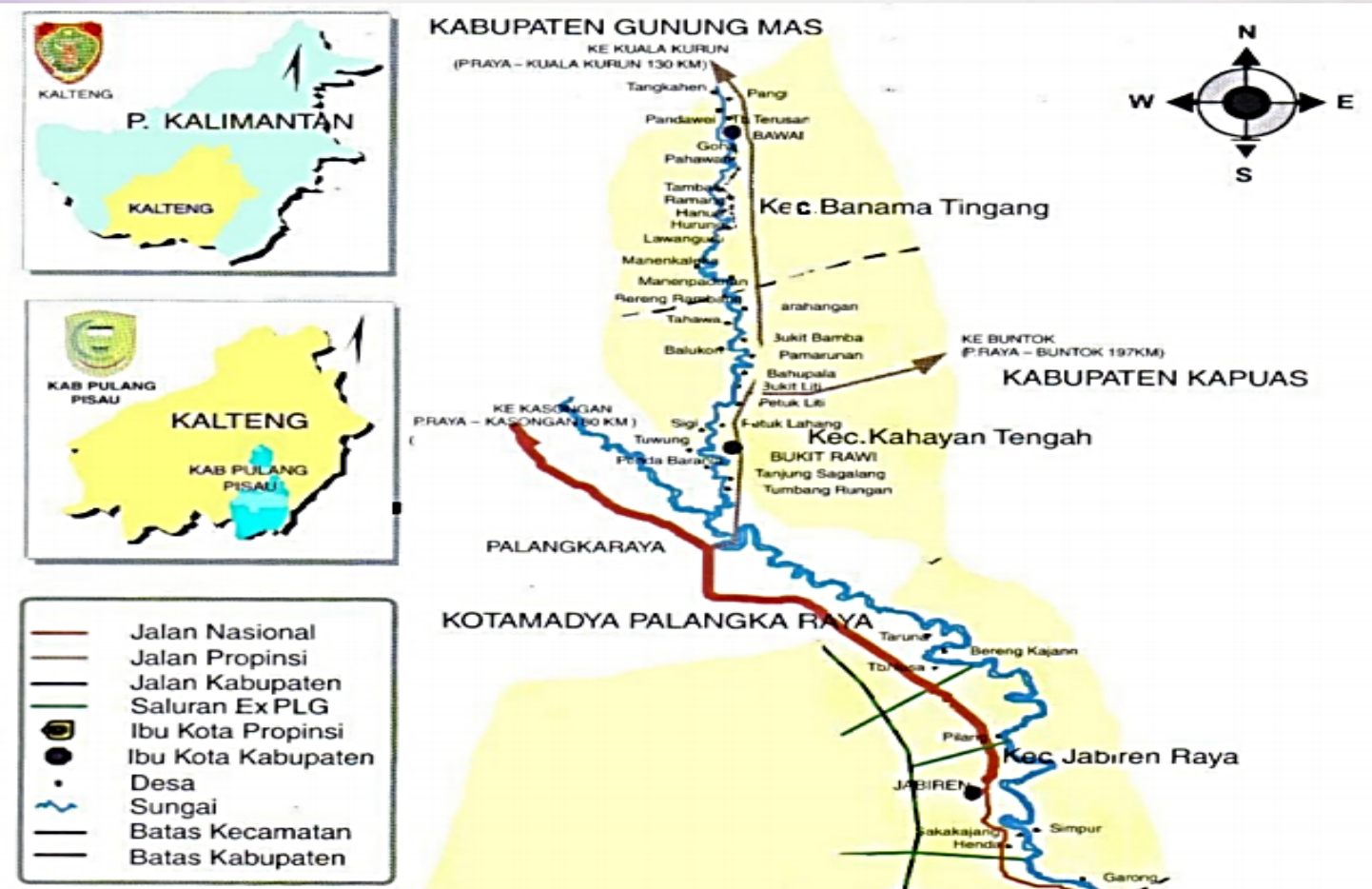

$$
\text { K }
$$
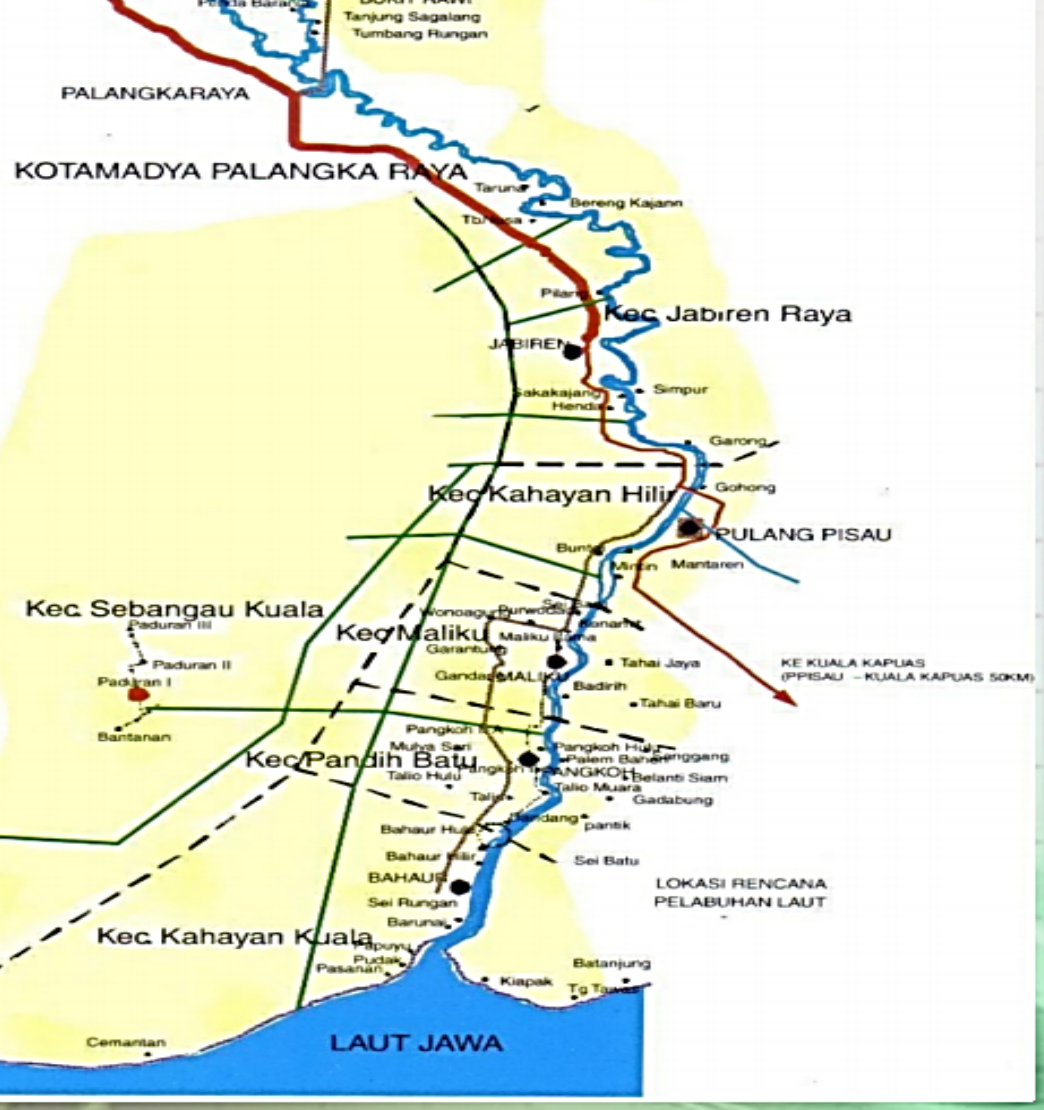

Figure 1: Location of the study area.

located between $10^{\circ}$ to $0^{\circ}$ South Longitude and $110^{\circ}$ to $120^{\circ}$ East longitude. East border of Pulang Pisau Regency is Kapuas Regency, the west bordered by Katingan Regency and Palangka Raya City. At north is bordered by Gunung Mas Regency meanwhile at south is bordered by Java Sea. Total area of Pulang Pisau Regency is $8.997 \mathrm{~km}^{2}$ or 899.700 $\mathrm{Ha}$ (5,85 \% from total area of Kalimantan Tengah Province), while total area of Kahayan Hilir District is $360 \mathrm{~km}^{2}$ (4 \% from total area of Pulang Pisau Regency).

\section{Selection of informant}

A total of 54 local peoples of different ages (18-65 years) were selected, and interviewed as key informants. The selected local peoples used medicinal plants for traditional health care in their daily activities.

\section{Data collection}

Ethnomedicinal data was collected through individual interviews using semi-structured interviews. Information regarding the plant's local name, medicinal uses, parts used, methods of preparation, and administration route were documented. Descriptive statistics were used to analyze the collected ethnomedicinal data.

\section{RESULTS AND DISCUSSION}

During the field survey in the study area, informant reported ethnomedicinal data of 28 species of medicinal plants. The 19 medicinal plant species distributed across 17 families, while families of 9 medicinal plant species unidentified. A total of 28 medicinal plants were recorded as being used to treat 19 different types of diseases as shown in Table 1. The family Anacardiaceae, Poaceae, Lamicaeae and Myrtaceae had the highest proportion of medicinal plants used (7\% each), followed by other families with only one plant species per family ( $4 \%$ each), and families of other unidentified plant species (21\%) (Figure 2). Further research is needed to identify the families and species of unidentified medicinal plants.

The most frequently utilized medicinal plant parts were roots (47\%), followed by bark (19\%), leaves and stem (9\% each), flowers $(6 \%)$, and 
Table 1: Medicinal plants used for treating human disease in Anjir Pulang Pisau Village.

\begin{tabular}{|c|c|c|c|c|c|}
\hline $\begin{array}{l}\text { Family and Scientific } \\
\text { name }\end{array}$ & Local name & Medicinal uses & Parts used & Methods of preparation & Administration route \\
\hline $\begin{array}{c}\text { Anacardiaceae } \\
\text { Bouea macrophylla Griff. }\end{array}$ & Ramania & Vomit, diarrhea & Bark & Decoction & Oral \\
\hline Campnosperma sp. & Terentang & Wound, vomit & Bark & Decoction & Oral \\
\hline \multirow[t]{2}{*}{$\begin{array}{c}\text { Annonaceae } \\
\text { Annona muricata L. }\end{array}$} & \multirow[t]{2}{*}{ Sirsak } & Stomach ache & Leaves & Crushed or pounded & Topical \\
\hline & & Hypertension & Roots & Decoction & Oral \\
\hline $\begin{array}{c}\text { Asparagaceae } \\
\text { Cordyline fruticosa (L.) } \\
\text { A.Chev. }\end{array}$ & Sawang & Vaginal discharge & Roots & Concoction & Oral \\
\hline $\begin{array}{l}\text { Blechnaceae } \\
\text { Stenochlaena palustris } \\
\text { (Burm.f.) Bedd. }\end{array}$ & Kelakai & Wound & Stem & $\begin{array}{l}\text { Crushed or pounded, } \\
\text { concoction }\end{array}$ & Topical \\
\hline $\begin{array}{c}\text { Bromeliaceae } \\
\text { Ananas comosus (L.) } \\
\text { Merr. }\end{array}$ & Nanas madu & Cholesterol & Fruits & Crushed or pounded & Oral \\
\hline $\begin{array}{l}\text { Cannabaceae } \\
\text { Trema tomentosa } \\
\text { (Roxb.) H. Hara }\end{array}$ & Kalanduyung & $\begin{array}{l}\text { Cough, respiratory tract } \\
\text { infection }\end{array}$ & Roots & Infusion & Oral \\
\hline $\begin{array}{c}\text { Dilleniaceae } \\
\text { Dillenia indica } \mathrm{L} .\end{array}$ & Simpur & Eye ache & Stem & Infusion & Ocular \\
\hline $\begin{array}{c}\text { Euphorbiaceae } \\
\text { Jatropha multifida L. }\end{array}$ & Betadine & Wound & Bark & Crushed or pounded & Topical \\
\hline $\begin{array}{l}\text { Lamicaeae } \\
\text { Orthosiphon aristatus } \\
\text { (Blume.) Miq. }\end{array}$ & Kumis kucing & Urinary tract infection & Roots & Decoction & Oral \\
\hline Plectranthus sp. & Bungeh tandang & Ear aches & Leaves & Crushed or pounded & Otic \\
\hline $\begin{array}{l}\text { Malvaceae } \\
\text { Hibiscus rosa-sinensis } \mathrm{L} \text {. } \\
\text { Meliaceae }\end{array}$ & Kembang sepatu & Hemorrhoid & Roots & Decoction & Oral \\
\hline $\begin{array}{l}\text { Sandoricum koetjape } \\
\text { (Burm.f.) Merr. }\end{array}$ & Kecapi & Stomach ache & Bark & Decoction & Oral \\
\hline $\begin{array}{l}\text { Menispermaceae } \\
\text { Arcangelisia flava (L.) } \\
\text { Merr. }\end{array}$ & Akar kuning & Liver & Roots & Decoction & Oral \\
\hline $\begin{array}{c}\text { Myrtaceae } \\
\text { Psidium guajava } \mathrm{L} .\end{array}$ & Jambu biji & Malaria & Seeds & Crushed or pounded & Oral \\
\hline $\begin{array}{c}\text { Rhodomyrtus } \\
\text { tomentosa (Aiton) } \\
\text { Hassk. }\end{array}$ & Mesisin & Diabetes & Roots & Decoction & Oral \\
\hline $\begin{array}{c}\text { Poaceae } \\
\text { Bambusa vulgaris } \\
\text { Schrad }\end{array}$ & Bambu kuning & Malaria & Stem & Decoction & Oral \\
\hline $\begin{array}{c}\text { Imperata cylindrica (L.) } \\
\text { Raeusch. }\end{array}$ & Alang-alang & Diabetes & Roots & Decoction & Oral \\
\hline $\begin{array}{c}\text { Rubiaceae } \\
\text { Morinda citrifolia } \mathrm{L} .\end{array}$ & Mengkudu & Hypertension & Fruits & $\begin{array}{l}\text { Crushed or pounded, } \\
\text { infusion }\end{array}$ & Oral \\
\hline
\end{tabular}




\begin{tabular}{|c|c|c|c|c|c|}
\hline $\begin{array}{c}\text { Solanaceae } \\
\text { Solanum torvum Sw. }\end{array}$ & Terung pipit & Diabetes & Roots & Decoction & Oral \\
\hline \multirow{2}{*}{$\begin{array}{l}\text { Thymelaeaceae } \\
\text { Phaleria macrocarpa } \\
\text { (Scheff.) Boerl. }\end{array}$} & \multirow{2}{*}{ Mahkota dewa } & Hypertension & Roots & Decoction & Oral \\
\hline & & Rheumatism & Bark & Decoction & Oral \\
\hline $\begin{array}{l}\text { Zingiberaceae } \\
\text { Curcuma zedoaria } \\
\text { (Christm.) Roscoe. }\end{array}$ & Kunyit putih & $\begin{array}{c}\text { Respiratory tract } \\
\text { infection, rheumatism, } \\
\text { wound }\end{array}$ & Rhizome & $\begin{array}{l}\text { Crushed or pounded, } \\
\text { infusion }\end{array}$ & Oral \\
\hline \multirow[t]{4}{*}{ Unidentified } & Hantangan & Diarrhea & Bark & Decoction & Oral \\
\hline & \multirow{2}{*}{ Lalangsatan } & Breast cancer & Roots & Infusion & Oral \\
\hline & & Wound & Leaves & Crushed or pounded & Topical \\
\hline & Kitui Bunu & Wound & Roots & Infusion & Oral \\
\hline \multirow[t]{4}{*}{ Unidentified } & Pukul jampa & Breast cancer & Roots & Crushed or pounded & Topical \\
\hline & \multirow{2}{*}{ Telayar } & Heart disease & Flowers & Infusion & Oral \\
\hline & & Breast cancer & Roots & Crushed or pounded & Topical \\
\hline & Umar & Vaginal discharge & Roots & Concoction & Oral \\
\hline
\end{tabular}

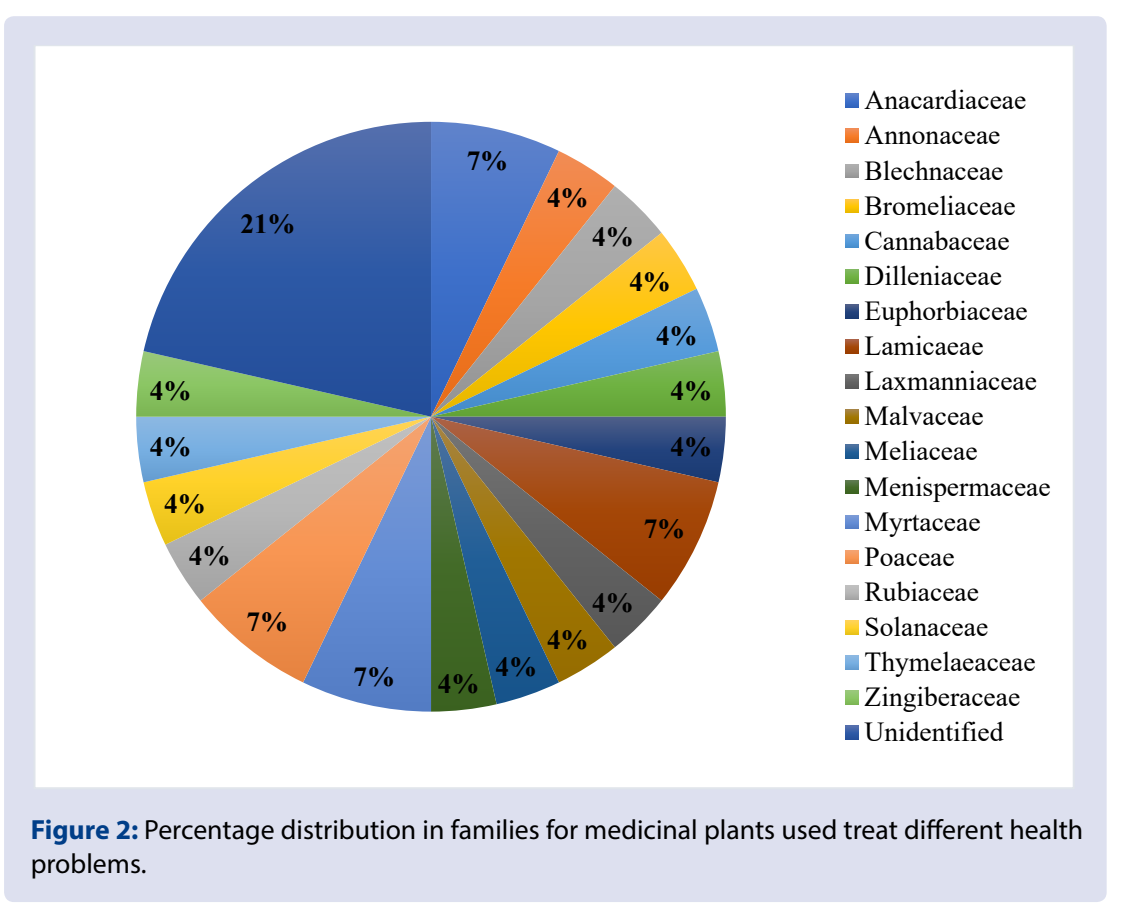

fruits, seeds, rhizome (3\% each) as shown in Figure 3. Most of the plant species were used to treat one disease, while some were used to treat two or more diseases. The most frequent plant species used to cure disease was Curcuma zedoaria (Christm.) Roscoe. (16\%), while Annona muricata L., Bouea macrophylla Griff., Campnosperma sp., Phaleria macrocarpa (Scheff.) Boerl., and Trema tomentosa (Roxb.) $\mathrm{H}$. Hara were each reported to treat $11 \%$ of the diseases (Figure 4). In terms of frequency of medicinal plant uses, the highest percentage of plant species $(21 \%)$ was used to treat wound, followed by breast cancer, diabetes, and hypertension (11\% each). Other diseases were treated with less than $10 \%$ of the medicinal plants recorded (Figure $5)$.
According to the available literatures, some of the reported medicinal plant species were found to have some phytochemical and biological activities. Bouea macrophylla Griff. can be used to treat vomit and diarrhea. This plant has numerous contents and one of them is flavonoid that function as antibacterial and antioxidant. Previous studies indicates that the total content of flavonoids in Bouea macrophylla Griff. leaf is higher than in Bouea macrophylla Griff. bark. Flavonoid are included in the largest group of phenol compounds that have very active properties to slow the growth of viruses, bacteria, and fungi. ${ }^{6}$ The root part of Cordyline fruticosa (L.) A.Chev. used by local people for vaginal discharge treatment. The plant of the genus Cordyline are very well known as source of steroidal saponins and cholestane glycosides. 


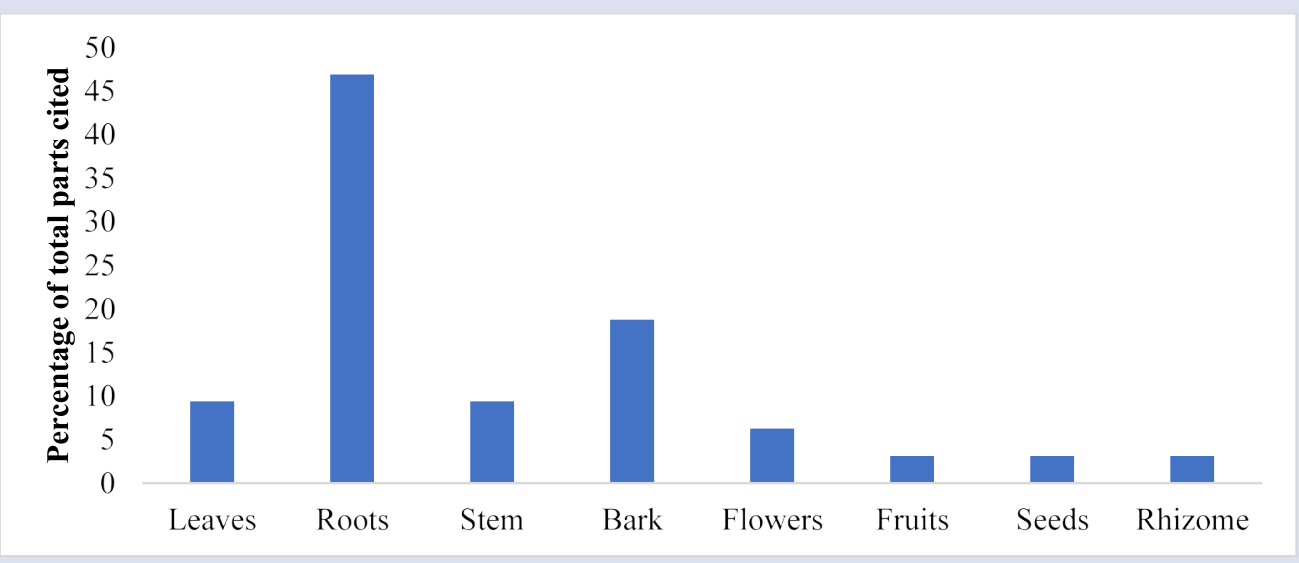

Figure 3: Plant parts used for medicinal purposes.

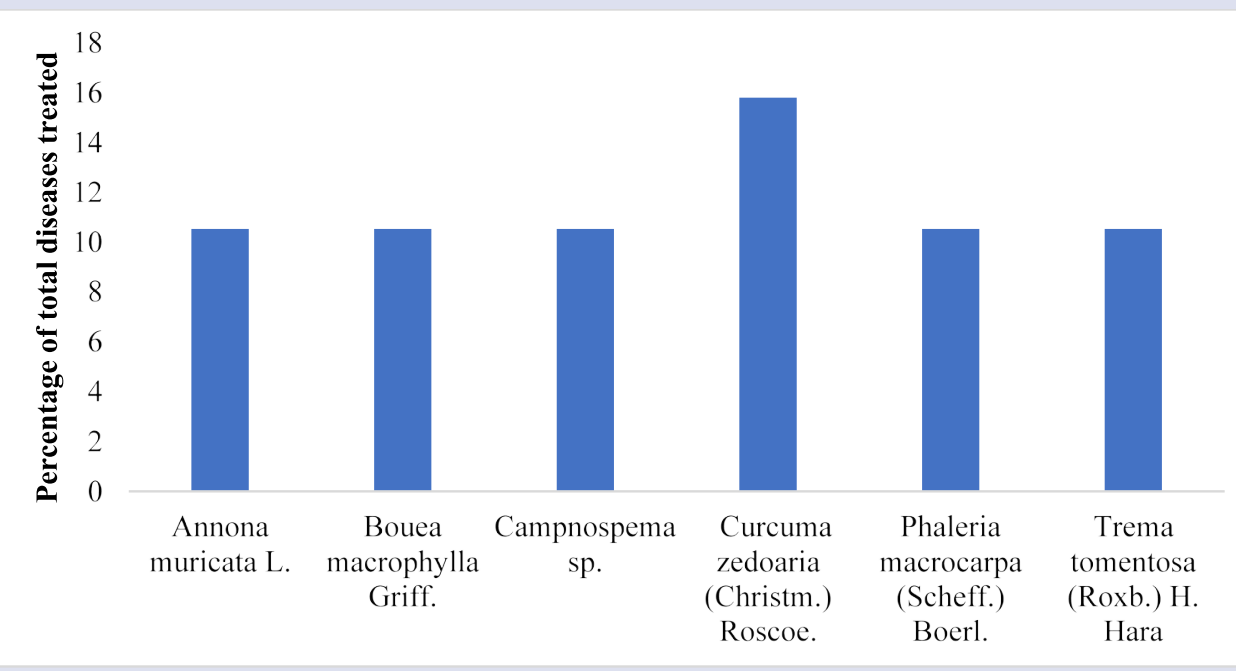

Figure 4: Medicinal plant species with highest percentage of total disease treated.

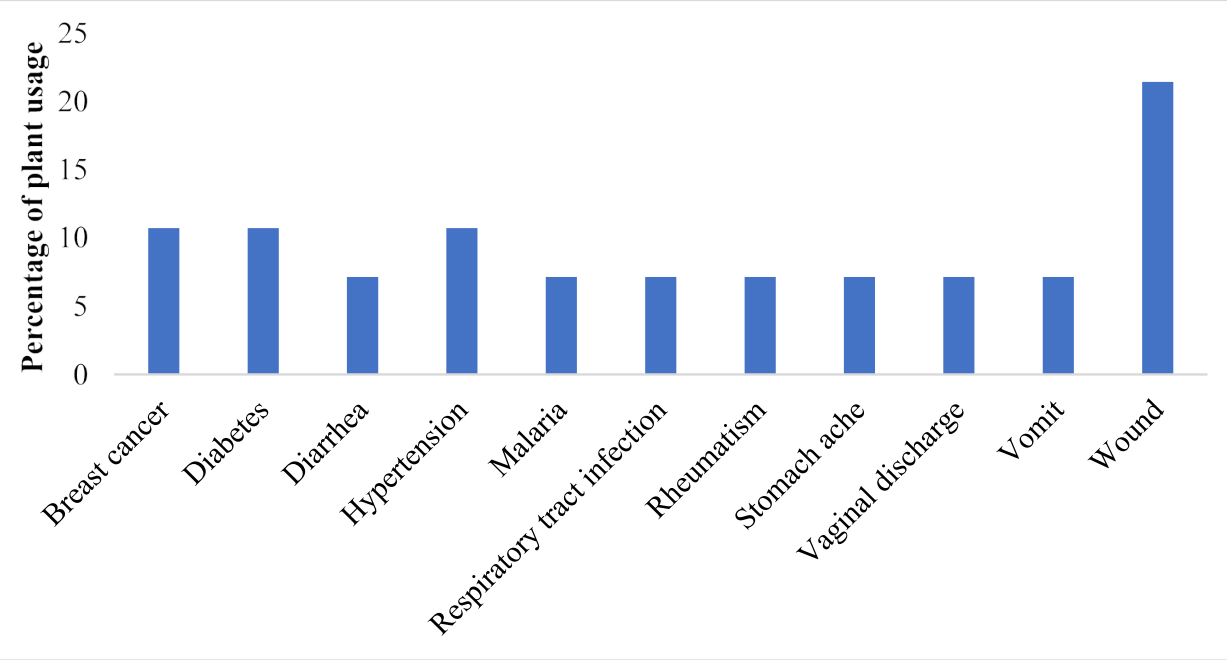

Figure 5: Frequency of medicinal plants uses to cure disease. 
Steroidal saponins was known for their biological actions, particularly cytotoxic, antimicrobial, antifungal, and in vivo antitumoral activities. ${ }^{7}$

Previous study about Ananas comosus (L.) Merr. revealed that ethanol extract of Ananas comosus (L.) Merr. leaves possess significant hypocholesterolemic activity. The acute toxicity also showed that the extract has a high safety profile as neither death nor symptomps associated with toxicity was observed at high dose level $(5 \mathrm{gm} / \mathrm{kg})$ in high cholesterol fed albino rats. ${ }^{8}$ Extract ethanol of Orthosiphon aristatus (Blume.) Miq. leaf produced the strong antimicrobial effect, inhibiting the growth of Candida albicans, Staphylococcus aureus, Enterococcus faecalis, Pseudomonas aeruginosa, Eschericia coli, Klebsiella pneumonia, Staphylococcus epidermidis, Proteus mirabilis. Some of these microorganism are the cause of urinary tract infections. ${ }^{9-10}$

The local people used Arcangelisia flava (L.) Merr. to cure liver. Higher dose of Arcangelisia flava (L.) Merr. extract shows hepatoprotective activity by preventing the elevation of serum transaminases and transferase levels. Eventually, no damage in the acetaminopheninduced rat's liver was observed. This plant modulates the expression of caspase 3 protein in dose-dependent manner. ${ }^{11}$ Ethobotanical studies have recorded the use of Psidium guajava L. via infusion and decoction of leaves, roots, and seeds to treat malaria. The pharmacological effect of this plant has investigated, both its in vitro and in vivo potential. ${ }^{12}$ The aqueous extract of the leaves of Bambusa vulgaris Schrad. Demonstrated important antiplasmodial activity against the Plasmodium parasites wit the chloroquinesensitive 3D7 P. falciparum being more susceptible. However, the antiplasmodial activity of stem of Bambusa vulgaris Schrad. still not found. ${ }^{13}$

Rhodomyrtus tomentosa (Aiton) Hassk. has been reported to contain various phytochemical compositions in many part of the plant, including steroids, flavonoids, and alkaloid compounds. Flavonoid and alkaloids are widely used in the form of the drug to treat diabetes, skin disorders and anti-inflammation. ${ }^{14}$ Curcuma zedoaria (Christm.) Roscoe. have been shown to contain bioactive molecules that possess pharmacological properties like antimicrobial, antiallergic, antihypertensive, antinociceptive and analgesic, hemagglutinating, antimutagenic and antioxidant, antiulcerogenic, antiproliferative, antifungal, larvicidal and pupicidal, cytotoxicity, anti-inflammatory, antiplatelet aggregation. ${ }^{15}$

Dillenia indica L. was known to contain antioxidant and antibacterial compounds, so it can be efficacious as an eye sore. ${ }^{16}$ Annona muricata L. and Sandoricum koetjape (Burm.f.) Merr. were known to have antibacterial compound, ${ }^{17,18}$ and both plant species were used to treat stomach ache by local people. Leaf part of Annona muricata L. also used by Ayta Communities in Dinalupihan, Bataan, for treat stomach ache. ${ }^{19}$ Jatropha multifida L. and Stenochlaena palustris (Burm.f.) Bedd. were used by local people to cure wound. The antibacterial assay of Jatropa multifida L. showed an in vitro growth inhibition of $P$. aeruginosa and $S$. aureus in dose-dependent manner. ${ }^{20}$ Stenochlaena palustris (Burm.f.) Bedd. was known as antioxidant and antimicrobial, so it can be efficacious to cure wound. ${ }^{21-22}$ Various studies reported that Annona muricata L., Morinda citrifolia L., and Phaleria macrocarpa (Scheff.) Boerl. can lower blood sugar levels. ${ }^{23-25}$

Majority of the plant remedies in this study were prepared by decoction (40\%), then by crushed or pounded (31\%), infusion (20\%), and concoction (9\%) (Figure 6). Some herbal preparations were taken by mixing with lime paste. Most medicinal plant preparations were taken orally (75\%), while $19 \%$ were used topically for disease such as wounds, breast cancers, and stomach ache (Figure 7). Various ethnomedicinal studies conducted elsewhere also reported that oral as the predominant route of administration..$^{26-28}$

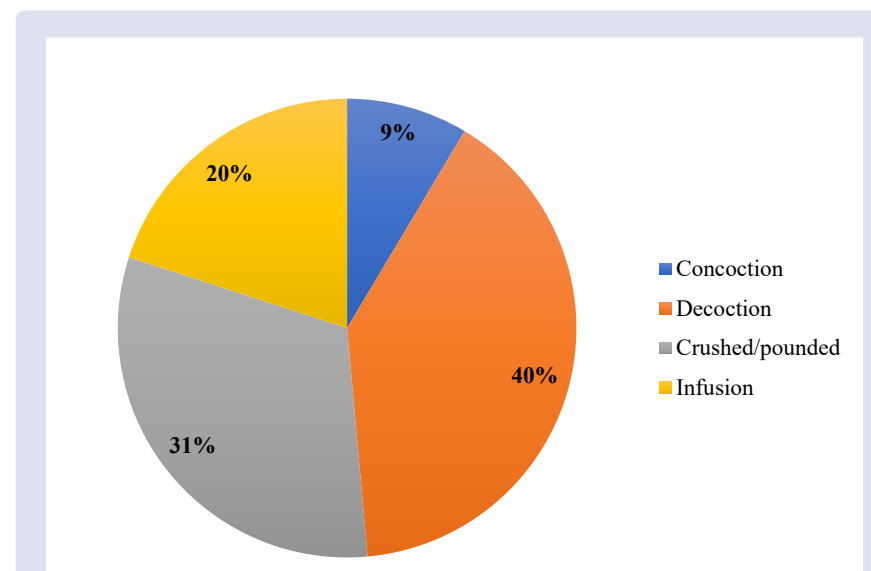

Figure 6: Medicinal plants preparation method.

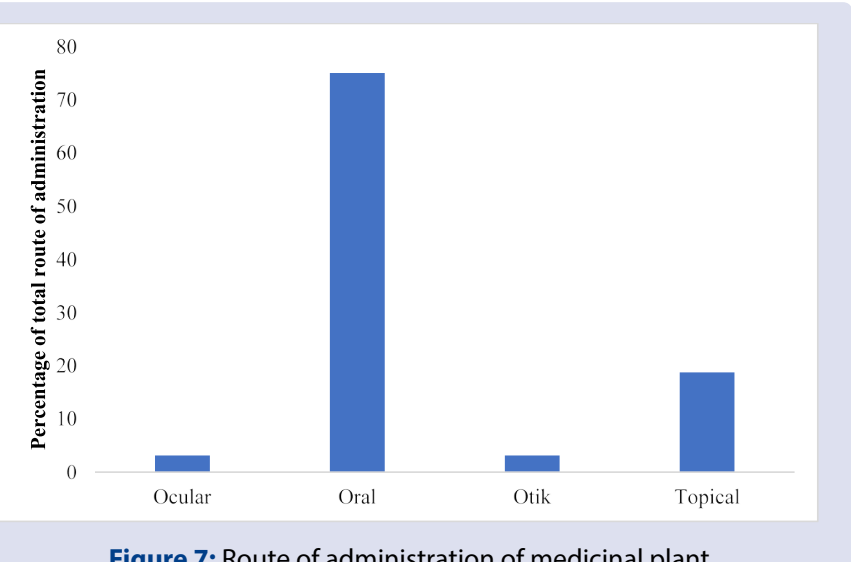

Figure 7: Route of administration of medicinal plant.

\section{CONCLUSION}

With this ethnomedicinal study, 28 medicinal plants were determined to be used for different medicinal purposes by local people. This study is the first on determination of medicinal plants used in Anjir Pulang Pisau Village. So, it is very important to preserve traditional culture on traditional medicine and survive for future generations. Further research is needed to identify unidentified family and plant species. Pharmacognostical and pharmacological studies are also needed for the identification of chemical compounds and proving the efficacy of medicinal plants used by local people.

\section{ACKNOWLEDGEMENT}

The authors would like to thank local people of Anjir Pulang Pisau Village who helped to collect information for this study.

\section{CONFLICTS OF INTEREST}

The authors declare no conflicts of interest.

\section{REFERENCES}

1. Hapsoh H, Hasanah Y. Cultivation of medicinal plants and spices. Medan: USU Press; 2011.

2. Walujo EB. Review: research ethnobotany in Indonesia and the future perspective. Biodiv. 2008;9(1):59-63.

3. Krismawati A, Sabran M. Management of plant genetic resources for specific medicinal plants in central kalimantan. Buletin Plasma Nutfah. 2006;12(1):1623.

4. Subeki, Matsuura H, Yamasaki M, Yamato O, Maede Y, Katakura K, et al. Effects of central kalimantan plant extracts on intraerythrocytic Babesia gibsonii in culture. J Vet Med Sci. 2004;66(7):871-4. 
5. Wijayakusuma MH. Healing with temulawak. Jakarta: Sarana Pustaka Prima; 2007.

6. Erwandi S, Taufiqurrahman I, Sukmana BI. The comparison of total flavonoid content in ramania (Bouea macrophylla Griffith) bark and leaf extract using maceration method. Dentino (Jur Ked Gigi). 2018;3(2):122-6.

7. Fouedjou RT, Teponno RB, Quassinti L, Bramucci M, Petrelli D, Vitalli LA, et al. Steroidal saponins from the leaves of Cordyline fruticosa (L.) A.Chev. and their cytotoxic and antimicrobial activity. Phytochem Let. 2014;7:62-8.

8. Islam MM, Mahabub-Uz-Zaman M, Aktar R, Ahmed NU. Hypocholesterolemic effect of ethanol extract of Ananas comosus (L.) Merr. leaves in high cholesterol fed albino rats. Int J Life Sci. 2011;5(1):57-62.

9. Reshi NA, Shankarsingh SM, Hodiyala GV. Evaluation of antibacterial potential of leaf and leaf derived callus extract of Orthosiphon aristatus (Blume.) Miq. Asian J Pharm Clin Res. 2017;10(5):245-9.

10. Romula A, Zuhud EAM, Rondevaldova J, Kokoska L. Screening of in vitro antimicrobial activity of plants used in traditional Indonesia medicine. Pharm Biol. 2018;56(1):287-93

11. Liem S, Rostinawati T, Lesmana R, Sumiwi SA, Milanda T, Mutakin, et al. Modulation of caspase-3 expression by Arcangelisia flava post acetaminopheninduced hepatoxicity in rat's liver. The Indonesian Biomed J. 2018;10(2):148-55.

12. Morais-Braga MFB, Carneiro JNP, Machado AJT, dos Santos ATL, Sales DL, Lima LF, et al. Psidium guajava L., from ethnobiology to scientific evaluation: elucidating, biactivity against pathogenic microorganisms. J Ethnopharm. 2016;194:1140-52

13. Komlaga G, Cojena S, Dickson RA, Beniddir MA, Suyyagh-Albouz S, Mensah MLK, et al. Antiplasmodial activity of selected medicinal plants used to treat malaria in Ghana. Parasitol Res. 2016;115(8):3185-95.

14. Hasibuan I, Ilyas S, Hanum S. Effect of leaf extract haramonting (Rhodomyrtus tomentosa) to lower blood sugar levels in mice induced by alloxan. Int J Pharm Tech Res. 2015;8(6):284-91.

15. Rajkumari S, Sanatombi K. Nutritional value, phytochemical composition, and biological activities of edible Curcuma species: a review. Int J Food Prop. 2017;20(S3):S2668-S87.

16. Yazan LS, Armania N. Dillenia species: a review of the traditional uses, active constituents and pharmacological properties from pre-clinical studies. Pharm Biol. 2014;52(7):890-7.
17. Olugbuyiro JAO, Omotosho OE, Taiwo OS, Ononiwu FO, Banwo AS, Akintokun $\mathrm{OA}$, et al. Antimicrobial activities and phytochemical properties of Anona muricata leaf. Covenant J Phys Life Sci. 2017;5(2):40-9.

18. Diansari E, Suwarso E, Dalimunthe A. Anti diarrhea effect of ethanol extract kecapi bark (Sandoricum koetjape Merr.) on male guinea pig induced with castor oil and bacteria Eschericia coli. Asian J Pharm Clin Res. 2018:11(special issue 1):73-6.

19. Tantengco OAG, Condes MLC, Estadilla HHT Ragrario EM Ethnobotanical survey of medicinal plants used by ayta communities in Dinalupihan, Bataan, Philippines. Pharmacogn J. 2018;10(5):859-70.

20. Anani $K$, Adjrah $Y$, Ameyapoh $Y$, Karou SD, Agbonon A, Souza CD, et al. Antimicrobial, anti-inflamatory and antioxidant activities of Jatropha multifida $L$. (Euphorbiaceae). Pharmacognosy Res. 2016;8(2):142-6.

21. Zuraini Z, Sasidharan S, Kaur SR, Nithiyayini M. Antimicrobial and antifungal activities of local edible fern Stenochlaena palustris (Burm.F.) Bedd. Pharmacology online. 2010;1:233-7.

22. Arullappan S, Sawai S, Chee LA, Mahandan M, Shanmugavelan R. Phytohemical screening and evaluation of cytotoxic effect and antioxidant activity of fractions isolated from Stenochlaena palustris (Burm.f.) Bedd leaves. Indian J Pharm Edu Res. 2017;51(4S):S735-S40.

23. Wirawan IGPI. Phaleria macrocarpa as antihypertension. J Majority 2015;4(5):24-8.

24. Ali M, Kenganora M, Manjula SN. Health benefits of Morinda citrifolia (Noni): a review. Pharmacogn J. 2016;8(4):321-34

25. Ismail S, Hayati N, Rahmawati N. Mechanism of action vasodilation Annona muricata $\mathrm{L}$. leaves extract mediated vascular smooth muscles. Proceedings of the 1st International Conference on Tropical Studies and Its Application; 2017 Nov 9; Samarinda: Indonesia. UK: IOP Publishing, 2018.

26. Tugume P, Kakudidi EK, Buyinza M, Namaalwa J, Kamatenesi M, Mucunguzi C, et al. Ethnobotanical survey of medicinal plant species used by communities around mabira central forest reserve, Uganda. J Ethnobiol Ethnomed. 2016;12(5):1-28.

27. TeklehaymanotT. An ethnobotanical survey of medicinal and edible plants of Yalo Woreda in Afar regional state, Ehiopia. J Ethnobiol Ethnomed. 2017;13(40):1-25.

28. Appiah KS, Oppong CP, Mardani HK, Omari RA, Kpabitey S, Amoatey CA, et al. Medicinal plant used in the Ejisu-Juaben Municipality, Southern Ghana: an ethnobotanical study. Medicines. 2019;6(1):1-27.

\section{GRAPHICAL ABSTRACT}

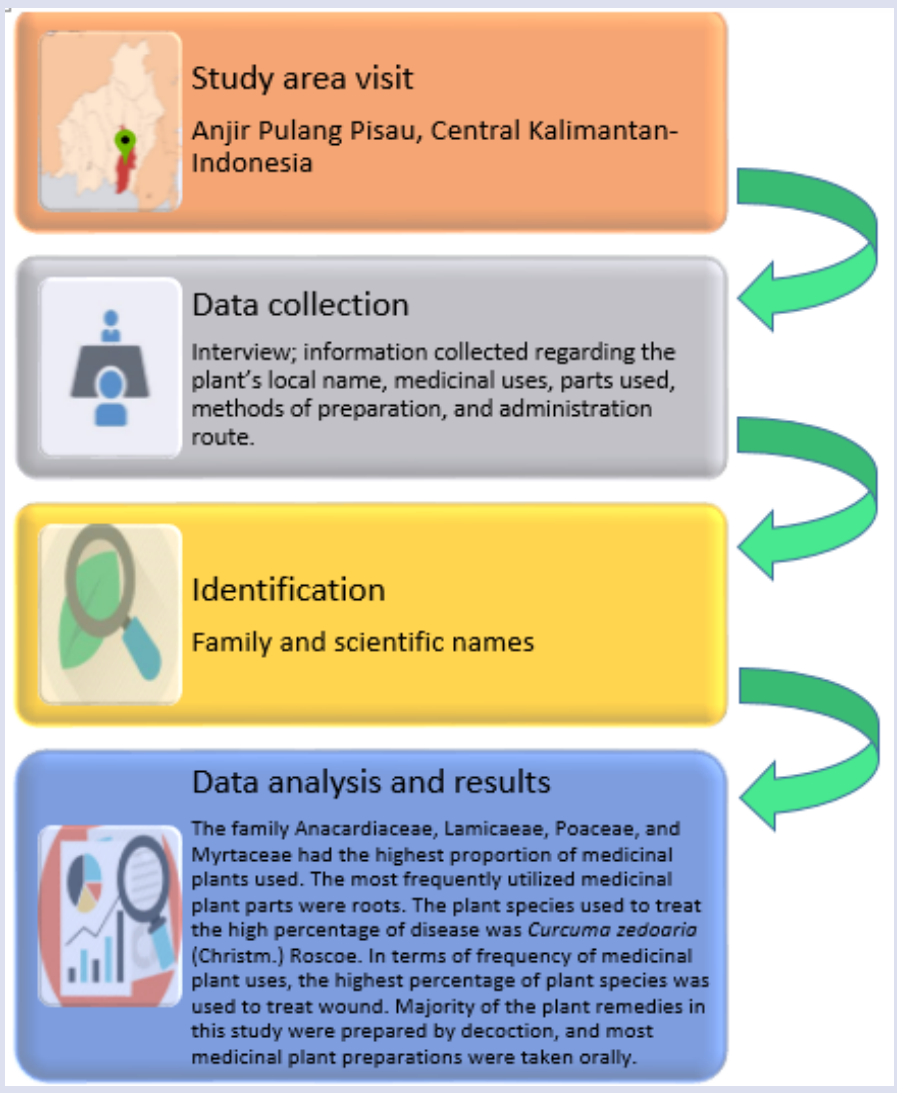




\section{ABOUT AUTHORS}

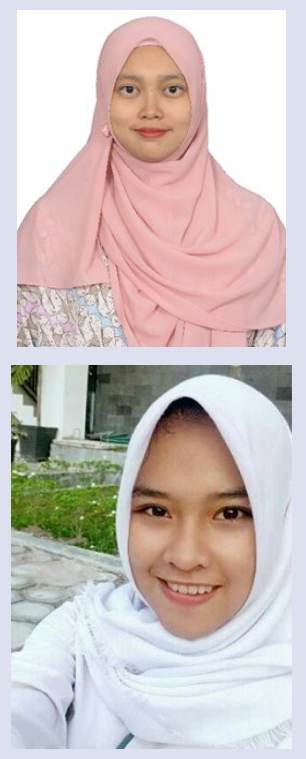

Susi Novaryatiin: Lecturer at the Department of Pharmacy, Faculty of Health Science, Universitas Muhammadiyah Palangkaraya, Central Kalimantan, Indonesia.

Indah Indah: Diploma graduate at the Department of Pharmacy, Faculty of Health Science, Universitas Muhammadiyah Palangkaraya, Central Kalimantan, Indonesia.

Cite this article: Novaryatiin S, Indah I. The Medicinal Plants Used in Anjir Pulang Pisau, Central Kalimantan-Indonesia. Pharmacog J. 2019;11(6)Suppl:1572-9 